\title{
Quality and safety assessment of goat milk collected from different regions of Mathura city
}

\author{
Sadhna Ojha, Vikas Pathak, Meena Goswami, S K Bharti and Tanuja
}

Received: 15 July 2020 / Accepted: 12 September 2020 / Published online: 27 December 2020

(C) Indian Dairy Association (India) 2020

\begin{abstract}
The present study was carried out for quality and safety assessment of goat milk from five different regions of Mathura city viz. Holigate, Sadar, Aurangabad, Chungi and Township. The milk samples were collected from dairy shops, vendors and milk producers and evaluated on the basis of various organoleptic tests, physico-chemical properties, proximate estimation and microbiological studies following the standard procedures. Among organolpetic tests, Chungi (70\%) and Township (90\%) samples had clearer appearance than the other area. All sample collected from township is white in color. Regarding texture/consistency of milk, the sample procured from $\mathrm{T}$ having normal consistency and normal odor. The COB test was positive in 20 and $10 \%$ samples of $\mathrm{H}$ and $\mathrm{S}$ areas only. There was no significant difference in temperature, $\mathrm{pH}$ and titrable acidity of milk of different areas. However, the specific gravity showed significant $(\mathrm{P}<0.05)$ difference among milk samples from different regions. The specific gravity of $\mathrm{S}$ area samples was significantly $(\mathrm{P}<0.05)$ higher than $\mathrm{H}, \mathrm{C}$ and $\mathrm{T}$ areas. The temperature, $\mathrm{pH}$ and specific gravity were lower however titrable acidity was higher than normal prescribed range in all milk samples. There was significant $(\mathrm{P}<0.05)$ difference for all proximate
\end{abstract}

Department of Livestock Products Technology, College of Veterinary Sciences and Animal Husbandry, DUVASU, Mathura-281001, India

Meena Goswami $(\square)$

Department of Livestock Products Technology, College of Veterinary Sciences and $\mathrm{AH}$

DUVASU, Mathura-281001, UP, India

e-mail Id: dr.goswami2008@yahoo.co.in

Mob no: +919997323852 parameters except fat content. The moisture contents of $\mathrm{H}, \mathrm{C}$ and $\mathrm{T}$ were significantly $(\mathrm{P}<0.05)$ higher but the SNF was lower than in $\mathrm{S}$ area. The protein percent of $\mathrm{H}$ region samples was significantly $(\mathrm{P}<0.05)$ lower than of other regions. The ash content of $\mathrm{S}$ region was significantly $(\mathrm{P}<0.05)$ higher than of $\mathrm{C}$ region, whereas total solid content of $\mathrm{S}$ region was significantly $(\mathrm{P}<0.05)$ higher than $\mathrm{H}, \mathrm{C}$ and $\mathrm{T}$ region. The mean total solid content of $\mathrm{A}$ was comparable to $\mathrm{C}, \mathrm{H}, \mathrm{T}$ and $\mathrm{S}$ region. Although proximate parameters of goat milk deviated from normal prescribed range but all samples were negative for adulteration eg. preservatives, neutralizers and others adulterants. There was no significant difference in DMC, SPC, Coliform count and Staphylococcus count of milk samples collected from different regions however all samples had higher microbial load than the prescribed limit.

Keywords: Adulteration, Goat milk, Organoleptic test, Preservative, Quality assessment

\section{Introduction}

Goats are supposed to be the first farm animal to be domesticated and known as poor men's cow because they have never been intensively farmed, that is why they are healthy, rarely suffer from mastitis. Being second largest in goat population, India also has some of the great milch breeds like Jamunapari, Beetal, Surti, Barbari. Goat milk is having better digestibility, alkalinity, buffering capacity and certain therapeutic values in medicine and human nutrition in comparison to cow's or human milk (Haenlein, 2014; Park, 1989; Park, 1994). It is responsible for production of several antimicrobial substances like bacteriocin and goat milk microbiota is also considered a good source of novel bacteriogenic Lactic acid bacteria (LAB) strains that can be exploited as an alternative for use as bio preservative in food (Perin, 2014). The milk of small ruminants such as goats is of particular economic interest in the developing countries. The production of this type of milk has to be a useful strategy to overcome the problems of under nutrition (Haenlein, 1984). It is easier to digest than cow's milk and may have certain therapeutic value (Haenlein, 2004). The major differences between goat's and cow's milk because of different proportions of the different kinds of casein, and also to the different structure and size of fat globules and protein micelles (Tziboula, 2003). All these 
differences could lead to the milk behaving differently during processing that could affect the final quality of goat s milk dairy products (Vargas, 2008). The efficient utilization of goat milk provides an opportunity to diversify the dairy market since it allows us to develop added value to the fermented products with particular characteristics compared to cow's milk.

Goat milk has similar properties to human milk it contain vitamin content just like human milk except lower content of folic acid, vitamin C and inositol Le-Jaouen (1981).Goat's milk contains vitamins, minerals, trace elements, electrolytes, enzymes, proteins, and fatty acids that are easily assimilated by the body. Therefore awareness about advantage of consumption of goats milk should be popularized so that production and utilization of goat's milk could be enhanced (Kumar, 2012). Goats milk shows therapeutic virtues for individuals with certain dietetic problems, thus physicians have traditionally recommended goats milk for infant and others allergic to cow milk. The research was done to assess the quality and safety paarmeters of market milk of goat milk because goat milk is very important to the health of human especially to the children and adolcent people because goat milk having easily digestible macro and micronutrient. Goat milk has better fat and protein digestibility and assimilation ability, along with this it also has higher mineral and vitamins composition which make it less allergic than other milk (Goswami et al. 2017). Despite of this fact, the problem of milk deficiency escalate due to minimum availability of resources of land, labour, capital, inadequate cooling facilities, insufficient feeding of animals etc. As population is rising day by day there is increased pressure on the land resources, availability of land for cultivation of food crops and fodder crops. All these factors contributed to certain malpractices. Milk adulteration is the most dangerous and hazardous practices in developing countries like India. Several factors like adulteration, presence of antibiotic, insecticides and pesticides residues and seasonal changes affect the physicochemical properties and composition of milk (Bashir et al. 2013). By taking all these points into consideration, the present study was carried out to assess the safety and quality parameters of goat milk with respect to physico-chemical properties, adulteration and microbiological quality in Mathura city.

\section{Materials and Methods}

The experiments were conducted in Department of Livestock Products Technology, College of Veterinary Sciences and Animal Husbandry, DUVASU, Mathura. Total 50 milk samples of goat were procured from local market/milk vendors etc. from 5 different regions (10 samples from each area) of Mathura i.e. Holigate $(\mathrm{H})$, Sadar (S), Aurangabad (A), Chungi (C) and Township (T). The $250 \mathrm{ml}$ raw milk was collected in sterile plastic bottle from bulk milk container of milk vendors and then put in to the ice box. The chemicals and culture media used in the study were procured from Hi Media Laboratories (P) Ltd, Mumbai and Tulip Diagnostics (P) Ltd., Goa.

\section{Analytical procedure}

\section{Platform tests}

Under platform test general appearance, odor, color, texture and clot on boiling test was performed (BIS, 2015).

\section{Physico-chemical Properties}

Under physico-chemical parameters, $\mathrm{pH}$ was determined by using digital pH meter (WTW, Germany, model pH 330i). The temperature of milk samples was taken with the help of a thermometer by immersing the same in the milk $(100 \mathrm{ml})$ contained in measuring cylinder. Specific gravity of milk sample was determined by method of Mahoney (1988). Fresh milk sample was filled sufficiently into a glass cylinder (100 ml capacity) and lactometer was held by the tip and inserted into the milk. The lactometer was allowed to float freely until it reached equilibrium. Then the lactometer reading at the lower meniscus was recorded. The thermometer was inserted immediately into the milk sample and the temperature of the milk was also recorded. The following formula was used to calculate the specific gravity of the milk:

$$
\text { Specific gravity }=(C L R / 1000)+1
$$

Where, $\mathrm{CLR}=$ corrected lactometer reading at a given temperature, i.e., for every degree $\mathrm{F}$ above $60^{\circ} \mathrm{F}, 0.1$ was added to the lactometer reading but for every degree $\mathrm{F}$ below $60^{\circ} \mathrm{F}, 0.1$ was subtracted from the lactometer reading.

Titratable acidity of the milk sample was determined according to the method of the AOAC (1990). Nine ml of milk sample was pipetted into a beaker and 3 to 5 drops of $1 \%$ phenolphthalein indicator was added to it. The milk sample was then titrated with $0.1 \mathrm{~N} \mathrm{NaOH}$ solution until a light pink color persisted. The titratable acidity calculated using the following formula and expressed as \% lactic acid

$$
\begin{gathered}
\text { Titratable acidity }(\%)=0.1 \mathrm{~N} \mathrm{NaOH}(\mathrm{ml}) \times 0.009 \times 100 / \text { Weight of } \\
\text { milk sample }
\end{gathered}
$$

\section{Proximate Estimation}

Among the proximate parameters, the fat content was determined by using Gerber's method (APHA, 1985). $10 \mathrm{ml}$ sulphuric acid $\left(\mathrm{H}_{2} \mathrm{SO}_{4}\right)$ was poured into butyrometer, after that $10.75 \mathrm{ml}$ of milk sample was slowly added into butyrometer followed by $1 \mathrm{ml}$ of amyl alcohol. The contents of butyrometer were thoroughly mixed and centrifuged at $1100 \mathrm{rpm}$ for 5 minutes. The percent fat was recorded directly from the butyrometer scale.

$$
\text { Fat } \%=\text { Upper reading }- \text { Lower reading }
$$

The moisture, protein and ash content were evaluated by following AOAC (1995) method. The SNF and Total solids contents were determined by ISI (1960) method. 


\section{Determination of preservatives}

The qualitative test for preservative addition in milk was evaluated as per ISI (1960).

\section{Boric acid}

$10 \mathrm{ml}$ of milk was taken in a test tube and $1 \mathrm{ml}$ of conc. hydrochloric acid $(\mathrm{HCl})$ was added and mixed it thoroughly. A strip of turmeric paper was dipped in acidified milk Appearance of characteristic red colour on the turmeric paper indicated the presence of boric acid or borax $\left(\mathrm{Na}_{2} \mathrm{~B}_{4} \mathrm{O}_{7} \cdot 10 \mathrm{H}_{2} \mathrm{O}\right)$. The red colour changed to dark blue green on addition of ammonium hydroxide, but reappeared on re-acidification with hydrochloric acid in case of positive samples. However no color change was indication of negative boric acid test.

\section{Formalin}

$10 \mathrm{ml}$ of milk was taken in a test tube. One or two drops of ferric chloride $\left(\mathrm{FeCl}_{3}\right)$ was added in it and mixed properly. After sufficient mixing $5 \mathrm{ml}$ of conc. sulphuric acid $\left(\mathrm{H}_{2} \mathrm{SO}_{4}\right)$ was poured from side wall of the test tube. Formation of brown color precipitate was the indication of negative formalin test.

\section{Hydrogen peroxide}

$5 \mathrm{ml}$ of fresh milk was taken in a test tube, an equal volume of sample milk was added, then two drops of $2 \%$ of paraphenylenediamine reagent was added and mixed it well. Blue color developed in the presence of $\mathrm{H}_{2} \mathrm{O}_{2}$, whereas pure milk sample remained white in color.

\section{Determination of Neutralizer}

\section{Carbonate/Bicarbonate}

The addition of carbonate / bicarbonate in milk was evaluated as per (Ayub et al. 2007) $5 \mathrm{ml}$ of milk with equal volume of $95 \%$ alcohol was taken in a test tube. A few drops of $0.1 \%(\mathrm{w} / \mathrm{v})$ alcoholic solution of rosalic acid was added If alkali was present a rose red colour appeared whereas brownish color was observed in pure milk.

\section{Determination of Adulterants}

\section{Cane sugar}

As per ISI (1960), $15 \mathrm{ml}$ of milk sample was taken in a test tube and $1 \mathrm{ml}$ of conc. hydrochloric acid was added. Then $0.1 \mathrm{gm}$ of Resorcinol reagent was added and mixed. The tube was placed in boiling water bath for $5 \mathrm{~min}$. and observed the colour change. Appearance of deep red colour indicated the presence of sucrose and there was no change in colour in pure milk samples.

\section{Starch}

As per ISI (1960), $3 \mathrm{ml}$ of milk sample was taken in a test tube. The milk was boiled over the flame, then allowed to cool the sample at room temperature. 1-2 drops of iodine solution was added to the test tube. Development of blue colour indicated the presence of starch which disappeared when sample was boiled and reappeared on cooling. If the test was negative for starch there was no change in colour of milk.

\section{Detection of urea}

As per ISI (1960), $5 \mathrm{ml}$ of milk was taken in a test tube and $1 / 2$ teaspoon of soyabean or arhar powder was added then mixed the content thoroughly by shaking the test tube. A red litmus paper was dipped in it after $5 \mathrm{~min}$. and removed it after $30 \mathrm{sec}$. A change in colour from red to blue indicated the presence of urea in the milk.

\section{Microbiological parameters}

The Direct microscopic count (DMC), standard plate count (SPC), Coliform count and staphylococcus count was determined as per the procedure described in APHA (1984).

\section{Statistical analysis}

Total 50 samples were taken from whole Mathura city, where 10 samples were taken from each area $(10 X 5=50)$. Therefore, sample size was $10(n=10)$ in each area. The data generated from various trials under each experiment were pooled and analyzed by statistical method of one way-ANOVA and Mean \pm S.E using SPSS Statistics 20.0 software package developed as per the procedure of Snedecor and Cochran (1994) and means were compared by using Dunkan's multiple range test (Dunkan, 1995).

\section{Results and Discussion}

\section{Platform tests}

The results for platform tests are presented in table 1 . The milk samples collected from $\mathrm{H}, \mathrm{S}, \mathrm{A}$ and $\mathrm{C}$ were 50, 50, 60 and $70 \%$ clear in appearance respectively, however $\mathrm{T}$ area had $90 \%$ clear milk samples. Out of total, 40, 50, 40, 30 and 10\% goat milk samples from $\mathrm{H}, \mathrm{S}, \mathrm{A}, \mathrm{C}$ and $\mathrm{T}$ respectively had visible dirt. $\mathrm{H}$ had 10\% samples with foreign matter, however foreign matter was not seen in any sample of S, A, C and T areas. T had more clear samples than other areas because consumers were procuring the goat milk directly from the milk producers and there was no involvement of vendors, however $\mathrm{H}$ samples were collected by milk vendors and middlemen. The visible dirt and foreign matter in milk might be due to ill maintenance of herd and unhygienic milking of goats. Out of total milk samples, 70, 80, 90 and 90 samples were of pure white color whereas 20, 20, 10 and $10 \%$ samples had light yellow color in $\mathrm{H}, \mathrm{S}, \mathrm{A}$ and $\mathrm{C}$ respectively. $10 \%$ samples of $\mathrm{H}$ area were 
pale yellow in color. The samples collected from T were $100 \%$ white in color. There was no dark yellow color in any milk sample. The variations in color of goat milk samples collected from five different regions of Mathura city might be because of variation in feed, breed and lactation period.

There were 80,90 and $90 \%$ milk samples with normal consistency in $\mathrm{H}, \mathrm{S}$ and $\mathrm{A}$ areas, however the $100 \%$ samples of $\mathrm{C}$ and $\mathrm{T}$ areas had normal texture. In H, S and A, 20, 10 and 10\% samples had watery consistency due to adulteration of water to increase the volume and to mask the light yellow color of milk. There was no sample observed with thick, ropy or slimy consistency. The presence of ropiness or slime in milk is the indication of longer period of storage and microbial load particularly due to Alkaligenes sp.

There were 70, 80, 80, 90 and 100\% milk samples with normal odor in $\mathrm{H}, \mathrm{S}, \mathrm{A}, \mathrm{C}$ and $\mathrm{T}$ respectively. There was no milk sample with rancid/oxidized odor in any region due to lower temperature of milk maintained in cans at $18 \pm 2^{\circ} \mathrm{C}$ and early morning milking of goats. The rancid/oxidized odor of milk is due to fat oxidation due to longer storage and growth of lipolytic microorganisms. $\mathrm{H}$, S, A and C samples had 20,10,20, and 10\% weedy odor, as well as the sample of $\mathrm{H}$ and $\mathrm{S}$ had $10 \%$ absorbed odor. Weedy odor of samples might be due feeding of concentrate to the animals, while absorbed odor because of storage of milk in poorly sanitized plastics/metal cans.

Among all samples collected from different regions of Mathura, 20 and 10 were positive for $\mathrm{COB}$ in $\mathrm{H}$ and $\mathrm{S}$ areas, however no milk sample was found positive for COB test in $\mathrm{A}, \mathrm{C}$ and $\mathrm{T}$ areas. Positive COB test shows higher bacterial load and titrable acidity as well as poor quality of milk. Wasiksiri et al. (2010) evaluated the platform test of goat milk samples from Southern Thailand and found that all sample were having white color, good natural smell and no sediment contamination, and $97.7 \%$ sample were negative for COB test.

\section{Physico-chemical properties}

The results for physic-chemical properties are presented in table 2. There was no significant difference between milk samples for temperature, $\mathrm{pH}$ and titrable acidity, however specific gravity value showed significant $(\mathrm{P}<0.05)$ difference among milk samples from different regions. The temperature of all milk samples was lower than normal range $\left(36-38^{\circ} \mathrm{C}\right)$ which might be due to storage of milk at lower temperature in cool cans. The variation in temperature of milk also might be due to certain factors like collection time, season and chilling of milk before sale. The normal $\mathrm{pH}$ of freshly drawn goat milk have been reported to range

Table1 Platform tests of raw milk of goat collected from different regions of Mathura

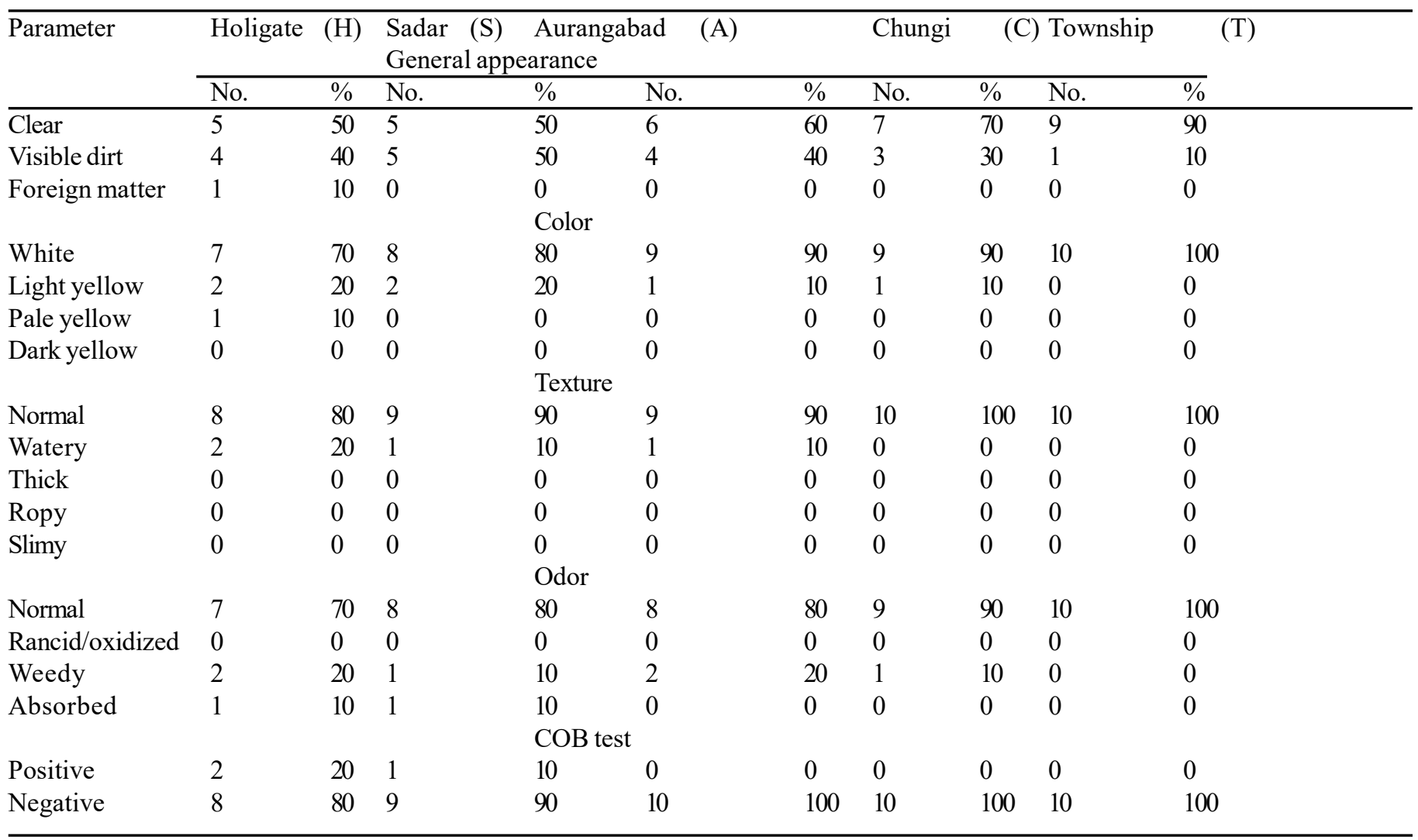


between 6.4-6.9 (Kumar et al. 2012) however in present study, all milk samples had lower $\mathrm{pH}$ than the described earlier. The possible reason of lower $\mathrm{pH}$ might be the production of lactic acid resulting from fermentation of lactose due to time gap between milking and sale. There was significant $(\mathrm{P}<0.05)$ difference in specific gravity of milk samples from different regions. The specific gravity of $\mathrm{S}$ samples was significantly $(\mathrm{P}<0.05)$ higher than $\mathrm{H}, \mathrm{C}$ and $\mathrm{T}$, whereas no significant difference was observed between $\mathrm{H}, \mathrm{C}$ and $\mathrm{T}$. The samples of $\mathrm{A}$ had comparable specific gravity with samples of $\mathrm{H}, \mathrm{C}$ and $\mathrm{T}$ as well as $\mathrm{S}$. The normal range of specific gravity of goat milk is 1.023-1.030 (Kumar et al. 2012). All milk samples had lower range than described value which might due to adulteration of milk with water and variation in breed and feeds.

The normal range of TA of goat milk is 0.17-0.19 (Sawaya et al. 1984). The titrable acidity of all milk samples were within the normal range, however S milk samples had slightly higher titrable acidity than normal range. The possible reason behind this finding might be the procurement of goat's milk from vendors. The vendors brought the milk from far areas in cool cans and the long time storage of milk at around $18-20^{\circ} \mathrm{C}$ might cause production of lactic acid by fermentable microorganisms resulting into higher titrable acidity.

\section{Proximate estimation}

The results for proximate parameters are presented in table 3 . There was a significant $(\mathrm{P}<0.05)$ difference for all proximate parameters except fat content in goat's milk samples collected from five different regions of Mathura city. The moisture content of $\mathrm{H}, \mathrm{C}$ and $\mathrm{T}$ was significantly $(\mathrm{P}<0.05)$ higher than $\mathrm{S}$, however there was no significant difference between $\mathrm{H}, \mathrm{C}$ and $\mathrm{T}$. The moisture content of A was comparable to $\mathrm{H}, \mathrm{C}, \mathrm{T}$ and $\mathrm{S}$.

Table2 Physico-chemical properties (Mean \pm SE) of raw milk of goat collected from different regions of Mathura

\begin{tabular}{lllllll}
\hline $\begin{array}{l}\text { Parameters } \\
(\%)\end{array}$ & $\begin{array}{l}\text { Holigate } \\
(\mathrm{H})\end{array}$ & $\begin{array}{l}\text { Sadar } \\
(\mathrm{S})\end{array}$ & $\begin{array}{l}\text { Aurangabad } \\
(\mathrm{A})\end{array}$ & $\begin{array}{l}\text { Chungi } \\
(\mathrm{C})\end{array}$ & $\begin{array}{l}\text { Township } \\
(\mathrm{T})\end{array}$ & $\begin{array}{l}\text { Treatment } \\
\text { mean }\end{array}$ \\
\hline Moisture & $88.42^{\mathrm{a}} \pm 0.36$ & $86.71^{\mathrm{b}} \pm 0.44$ & $87.69^{\mathrm{ab}} \pm 0.27$ & $88.51^{\mathrm{a}} \pm 0.17$ & $88.30^{\mathrm{a}} \pm 0.18$ & $87.93 \pm 0.16$ \\
Fat & $3.36 \pm 0.10$ & $3.47 \pm 0.09$ & $3.59 \pm 0.07$ & $3.22 \pm 0.08$ & $3.39 \pm 0.09$ & $3.40 \pm 0.04$ \\
SNF & $7.79^{\mathrm{b}} \pm 0.31$ & $9.06^{\mathrm{a}} \pm 0.17$ & $8.40^{\mathrm{ab}} \pm 0.20$ & $7.95^{\mathrm{b}} \pm 0.13$ & $7.91^{\mathrm{b}} \pm 0.15$ & $8.22 \pm 0.11$ \\
Protein & $2.48^{\mathrm{b}} \pm 0.25$ & $3.14^{\mathrm{a}} \pm 0.06$ & $3.14^{\mathrm{a}} \pm 0.07$ & $3.01^{\mathrm{a}} \pm 0.04$ & $3.01^{\mathrm{a}} \pm 0.06$ & $2.96 \pm 0.06$ \\
Ash & $0.69^{\mathrm{ab}} \pm 0.01$ & $0.72^{\mathrm{a}} \pm 0.01$ & $0.71^{\mathrm{ab}} \pm 0.01$ & $0.66^{\mathrm{b}} \pm 0.11$ & $0.69^{\mathrm{ab}} \pm 0.01$ & $0.70 \pm 0.01$ \\
Total solids & $11.15^{\mathrm{b}} \pm 0.34$ & $12.53^{\mathrm{a}} \pm 0.22$ & $11.99^{\mathrm{ab}} \pm 0.26$ & $11.05^{\mathrm{b}} \pm 0.15$ & $11.30^{\mathrm{b}} \pm 0.16$ & $11.60 \pm 0.13$ \\
\hline
\end{tabular}

Table 3 Proximate estimation (Mean \pm SE) of raw milk of goat collected from different regions of Mathura

\begin{tabular}{lllllll}
\hline Parameter & Holigate $(\mathrm{H})$ & Sadar $(\mathrm{S})$ & Aurangabad $(\mathrm{A})$ & Chungi $(\mathrm{C})$ & Township $(\mathrm{T})$ & Treatment mean \\
\hline Temperature & $19.72 \pm 0.44$ & $19.71 \pm 0.42$ & $19.90 \pm 0.37$ & $19.02 \pm 0.38$ & $19.98 \pm 0.23$ & $19.66 \pm 0.16$ \\
$\mathrm{pH}$ & $5.62 \pm 0.08$ & $5.66 \pm 0.038$ & $5.57 \pm 0.063$ & $5.67 \pm 0.59$ & $5.70 \pm 0.081$ & $5.64 \pm 0.029$ \\
Sp gravity & $1.024^{\mathrm{b}} \pm 0.01$ & $1.029^{\mathrm{a}} \pm 0.01$ & $1.027^{\mathrm{a}} \pm 0.01$ & $1.025^{\mathrm{b}} \pm 0.01$ & $1.025^{\mathrm{b}} \pm 0.01$ & $1.026 \pm 0.01$ \\
Titrable acidity & $0.18 \pm 0.01$ & $0.20 \pm 0.02$ & $0.17 \pm 0.15$ & $0.17 \pm 0.10$ & $0.19 \pm 0.23$ & $0.18 \pm 0.08$ \\
\hline
\end{tabular}

Table4 Screening of raw milk samples of goat for various preservatives

\begin{tabular}{lllllllllll}
\hline & Holigate $(\mathrm{H})$ & & Sadar(S) & & Aurangabad (A) & & Chungi (C) & & Township (T) \\
\hline Preservative & + & - & + & - & + & - & + & - & + & - \\
Formalin & 0 & 10 & 0 & 10 & 0 & 10 & 0 & 10 & 0 & 10 \\
Boric acid & 0 & 10 & 0 & 10 & 0 & 10 & 0 & 10 & 0 & 10 \\
Hydrogen & 0 & 10 & 0 & 10 & 0 & 10 & 0 & 10 & 0 & 10 \\
peroxide & & & & & & & & & \\
\hline
\end{tabular}

Table5 Screening of raw milk samples of goat for various preservatives

\begin{tabular}{|c|c|c|c|c|c|c|c|c|c|c|c|}
\hline \multirow[b]{2}{*}{ Adulterant } & \multicolumn{2}{|c|}{ Holigate $(\mathrm{H})$} & \multicolumn{2}{|c|}{ Sadar (S) } & \multicolumn{2}{|c|}{ Aurangabad(A) } & \multicolumn{2}{|c|}{ Chungi(C) } & \multicolumn{3}{|c|}{ Township(T) } \\
\hline & + & - & + & - & + & - & + & - & + & & - \\
\hline Carbonate/ & onate & 0 & 10 & 0 & 10 & 0 & 10 & 0 & 10 & 0 & 10 \\
\hline Starch & 0 & 10 & 0 & 10 & 0 & 10 & 0 & 10 & 0 & & 10 \\
\hline Cane sugar & 0 & 10 & 0 & 10 & 0 & 10 & 0 & 10 & 0 & & 10 \\
\hline Urea & 0 & 10 & 0 & 10 & 0 & 10 & 0 & 10 & 0 & & 10 \\
\hline
\end{tabular}


Table6 Microbiological studies (Mean \pm SE) of raw milk of goat collected from different regions of Mathura $\left(\log _{10} \mathrm{cfu} / \mathrm{ml}\right)$

\begin{tabular}{lllllll}
\hline Parameter & $\begin{array}{l}\text { Holigate } \\
(\mathrm{H})\end{array}$ & $\begin{array}{l}\text { Sadar } \\
(\mathrm{S})\end{array}$ & $\begin{array}{l}\text { Aurangabad } \\
(\mathrm{A})\end{array}$ & $\begin{array}{l}\text { Chungi } \\
(\mathrm{C})\end{array}$ & $\begin{array}{l}\text { Township } \\
(\mathrm{T})\end{array}$ & Treatment mean \\
\hline $\mathrm{DMC}$ & $6.692 \pm 0.16$ & $6.719 \pm 0.02$ & $6.716 \pm 0.04$ & $6.755 \pm 0.02$ & $6.707 \pm 0.03$ & $6.718 \pm 0.03$ \\
SPC & $7.980 \pm 0.20$ & $7.933 \pm 0.19$ & $8.393 \pm 0.19$ & $7.862 \pm 0.22$ & $8.054 \pm 0.16$ & $8.044 \pm 0.08$ \\
Coliform count & $5.306 \pm 0.15$ & $5.145 \pm 0.17$ & $5.451 \pm 0.19$ & $4.888 \pm 0.21$ & $5.073 \pm 0.22$ & $5.173 \pm 0.08$ \\
Staphylococcus & $4.794 \pm 0.13$ & $4.815 \pm 0.16$ & $5.078 \pm 0.14$ & $5.267 \pm 0.25$ & $4.909 \pm 0.20$ & $4.972 \pm 0.08$ \\
count & & & & & & \\
\hline
\end{tabular}

Comparatively lower moisture percent in S samples than other areas could be correlated to higher specific gravity of $\mathrm{S}$ areas sample than the samples of other areas. The moisture \% of all milk samples showed slightly higher value than the normal range. The normal moisture content of goat milk is $86.5 \%(\mathrm{De}, 1991)$. It might be due to adulteration of milk with water as well as variation in feeding, nutrition and the climatic conditions. Imran et al. (2008) recorded the moisture content of goat milk collected from local markets of Peshawar in Pakistan as $80.5 \%$.

There was no significant difference in fat content of different milk samples. The fat percent of all samples showed lower value than normal range which might be due to variations in breed, lactation period, feed etc. The normal fat $\%$ of goat milk is $3.5 \%$ (De, 1991). Many milk samples of goat's milk were collected directly from milk producers due to availability of less milk from vendors. The price of the goat milk is quite high, further the producer normally uses goat's milk for their own household purposes, therefore there is very less possibility of practicing skimming. The SNF of $\mathrm{S}$ region was significantly $(\mathrm{P}<0.05)$ higher than $\mathrm{H}, \mathrm{C}$ and $\mathrm{T}$, however there was no significant difference between $\mathrm{H}, \mathrm{C}$ and T. The SNF content of A was comparable to $\mathrm{H}$, C, T and S. Park (2006) reported the average SNF \% of goat's milk to be around $8.9 \%$. The protein percent of milk of $\mathrm{H}$ region was significantly $(\mathrm{P}<0.05)$ lower than other regions. There was no significant difference between $\mathrm{S}, \mathrm{A}, \mathrm{C}$ and $\mathrm{T}$. All milk samples showed lower of protein content than normal prescribed range. The possible reason behind this might be the rearing of non descript breeds of goats for milk purposes by milk producers in these areas. The normal protein content of goat milk is $3.5 \%$ (De, 1991). The ash content of milk of $S$ region was significantly $(\mathrm{P}<0.05)$ higher than of $\mathrm{C}$ region, however samples of $\mathrm{H}, \mathrm{A}$ and $\mathrm{T}$ was comparable with $\mathrm{S}$ and $\mathrm{C}$. The variation in ash of goat milk might be caused by several factors such as season, stages of lactation, breed, diet, individual animal and environmental management conditions (Haenlein, 2004). The total solid content of $\mathrm{S}$ region milk was significantly $(\mathrm{P}<0.05)$ higher than that of $\mathrm{H}$, $\mathrm{C}$ and $\mathrm{T}$ region, however there was no significant difference in between $\mathrm{H}, \mathrm{C}$ and $\mathrm{T}$ region samples. The mean total solid content of A was comparable to $\mathrm{C}, \mathrm{H}$ T and $\mathrm{S}$. All samples had TS content lower than prescribed normal range. The normal value of TS of goat milk is $13 \%$ (Kumar et al. 1991). Gaddour et al. (2013) observed higher values of $\mathrm{pH}$, total acidity, density, viscosity, protein, fat and ash in goat milk samples of southern Tunisia arid zone.

\section{Preservatives and adulterants}

The results for presence of preservatives and adulterants are presented in table 4 and table5. All milk samples collected from five different regions of Mathura were negative for preservatives' adulteration viz. Formalin, boric acid and hydrogen peroxide. The possible reason behind this might be the use of goat's milk for own household purposes by milk producers and higher price due to medicinal values. All milk samples of goat were negative for any kind of adulteration i.e. neutralizer and others like starch, cane sugar, and urea tested in laboratory.

\section{Microbiological studies}

The results for microbiological studies are presented in table 6 . There was no significance difference in DMC, SPC, Coliform count and Staphylococcus count of milk samples collected from different regions. All the samples had higher microbial load than the prescribed limit. It might be due to prolong storage, faulty transportation and handling conditions, infected of udder, unhygienic milking procedure and poor water quality used for cleaning as well as unsterilized equipment. Saad et al. (2013) also reported that higher Staphylococcus count (7.5 to $7.4 \mathrm{cfu} / \mathrm{ml})$, and Coliform count ( 7.3 to $7.5 \log \mathrm{mpn} / \mathrm{ml}$ ) in goat milk samples at Cairo and Giza District of Egypt.

\section{Conclusions}

Goat milk collected from different dairy shops, vendors and milk producers of different regions of Mathura city were free from any kind of adulteration and preservative addition; however proximate parameters were deviated from the normal range. All milk samples had higher microbial load than the prescribed limit by BIS due to poor hygienic condition and sanitation during milking, handling practices and transportation as well as use of unclean utensils. The consumption of poor quality milk may lead to serious human health problems, so it becomes necessary to implement stringent quality control system and regular check. FSSAI standards should be applied at each and every step starting from farm level to final consumption by producers, sellers and consumers to have wholesome, safe and nutritious milk. 


\section{References}

AOAC (1990) Official Methods of Analysis. Association of Official Analytical Chemists Inc.Virginia, USA

AOAC (1995) Official Method of Analysis. 16th Edn. Association of Official Analytical Chemists, Washington, DC

APHA (1984) Compendium of Methods for Microbiological Examination of Foods. 2nd Edn. American Public Health Association, Washington

APHA (1985) Standard methods for the Examination of Dairy Products. INC $15^{\text {th }}$ Ed. American Public Health Association, Washington, DC

Ayub M, Ahmad Q, Abbas M, Qazi IM, Khattak IA (2007) Composition and adulteration analysis of milk samples. Sarhad J Agric 23: 11281130

Bureau of Indian Standards (2015). Practical on technology of milk and milk products. AgriInfo.in@2015

De SK (1991) Outlines of Dairy Technology $1^{\text {st }}$ Edition New Delhi: Oxford University. Pp 15-28

Gaddour A, Najari S, Aroum S, Abdennebi M (2013) Local goat milk valorization and dairy products characterization in the southern Tunisia arid zone. Int J Curr Microbiol App Sci 2: 318-323

Goswami M, Bharti SK, Tewari A, Sharma H, Karunakara KN, Khanam T (2017) Implication of functional ingredients of goat milk to develop functional foods. J Anim Feed Sci Technol 5: 65-72

Haenlein GFW (2004) Goat milk in human nutrition. Small Ruminant Res 51: $155-163$

Haenlein GFW, Caccese R (1984) Goat milk versus cow milk. In: G.F.W. Haenlein and D.L. Ace (Eds.) Extension Goat Handbook. USDA Publ., Washington, DC, E-1, pp 1-4

Imran M, Khan H, Hassan SS, Khan R (2008) Physicochemical characteristics of various milk samples available in Pakistan. J Zhejiang Univ Sci B 9: 546-551

IS 1479 (Part II) - 1961 (Reaffirmed 1997) Methods of test for Dairy Industry -Chemical Analysis of Milk. Bureau of Indian Standards, New Delhi
Kumar S, Kumar B, Kumar R, Kumar S, Khatkar SK, Kanawjia KS (2012) Nutritional features of goat. Indian J Dairy Sci 65: 266-273

Le-Jaouen JC (1981) Milking and the Technology of Milk and Milk Products. In "Goat Production" Ed. by Gall, G. Academic. Press, London Ltd. Chap. 11: 345-377

Mahoney OF (1988) Rural Dairy Technology- Experiences in Ethiopia. ILCA manual No 4. Dairy Technology Unit. ILCA, Addis Abeba, Ethiopia

Park YW, Chukwu HI. (1989) Trace mineral concentrations in goat milk from French-Alpine and Anglo-Nubian breeds during the first 5 months of lactation. J Food Compos Anal 2:161-169

Park YW (1994) Hypo-allergenic and therapeutic significance of goat milk. Small Ruminant Res 14: 151-159

Park YW (2006) Goat milk chemistry and nutrition. In: Park,Y.W., Haenlein, G.F.W. (Eds.), Handbook of Milk of Non-bovine Mammals. Blackwell Publishing Professional, Oxford, UK/Ames, Iowa. 34-58

Perin 1m, Nero la (2014) Antagonistic lactic acid bacteria isolated from goat milk and identification of a novel nisin variant Lactococcus lactis. BMC Microbiol 12: 14-36

Saad MF, Hafiz NM, Salwa AA. (2013) Microbiological quality evaluation of raw goat's milk in egypt. Int J Bio Pharma A Sci 2: 1837-1848

Sawaya WN, Safi WJ, Al-Shahat AF, Al- Mohammad MM (1984) Chemical composition and nutritive value of goat milk. J Dairy Sci 67: 16551659

Tziboula-Clarke A (2003) Goat milk. In H Roginnski, J W Fuquay, P F Fox (Editors), Encyclopedia of dairy sciences, London, UK: Academic UK: Woodhead Publishing Ltd 2: 1270-1279.

Vargas M, Chafer M, Albors A, Chiralt A, Gonzalez-Martinez C (2008) Physicochemical and sensory characteristics of yogurt produced from mixtures of cows and goats milk. Int Dairy J 18: 11461152

Wasiksiri TS, Chethanond U, Pongprayoon S, Srimai S, Nasae B. (2010) Quality aspects of raw goat milk in Lower Southern Thailand. Songklanakarin J Sci Technol 32: 109-113 